\title{
Tensile Strength of Short Headed Anchors Embedded in Steel Fibrous Concrete
}

\author{
S. A. Al-Ta'an* A. A. Mohammed**
}

ABSTRACT

This paper deals with the tensile behaviour and strength of cast-in-place short headed anchor bolts embedded in both normal concrete (NC) and steel fibre reinforced concrete (SFRC). Four volume fractions $\left(v_{f}=0.4 \%, 0.8 \%, 1.2 \%\right.$, and $\left.1.6 \%\right)$, two aspect ratios $\left(l_{f} / d_{f}=19.63,36.33\right)$, three bolt diameters $\left(d_{b}=8,10,12 \mathrm{~mm}\right)$, and four embedment depths $\left(h_{e f}=25,37.5,50,62.5 \mathrm{~mm}\right)$ were used. More than (108) specimens were tested under monotonic tensile loading. Only (90) specimens were failed by large concrete failure cone exceeding the dimensions of the specimen and the cone breaks into pieces in most cases (concrete failure), while the other specimens were failed by yielding or fracture of the bolts (steel failure). Tests results showed that breakout capacity ( $\left.P_{u}\right)$ of the anchors were significantly enhanced by the addition of steel fibers to concrete and the size of the failure cone in (SFRC) specimens were smaller than the size of failure cones in (NC).

Key word: Breakout capacity, cast-in-place, failure cone, headed anchor bolt, pullout test, steel fibers.

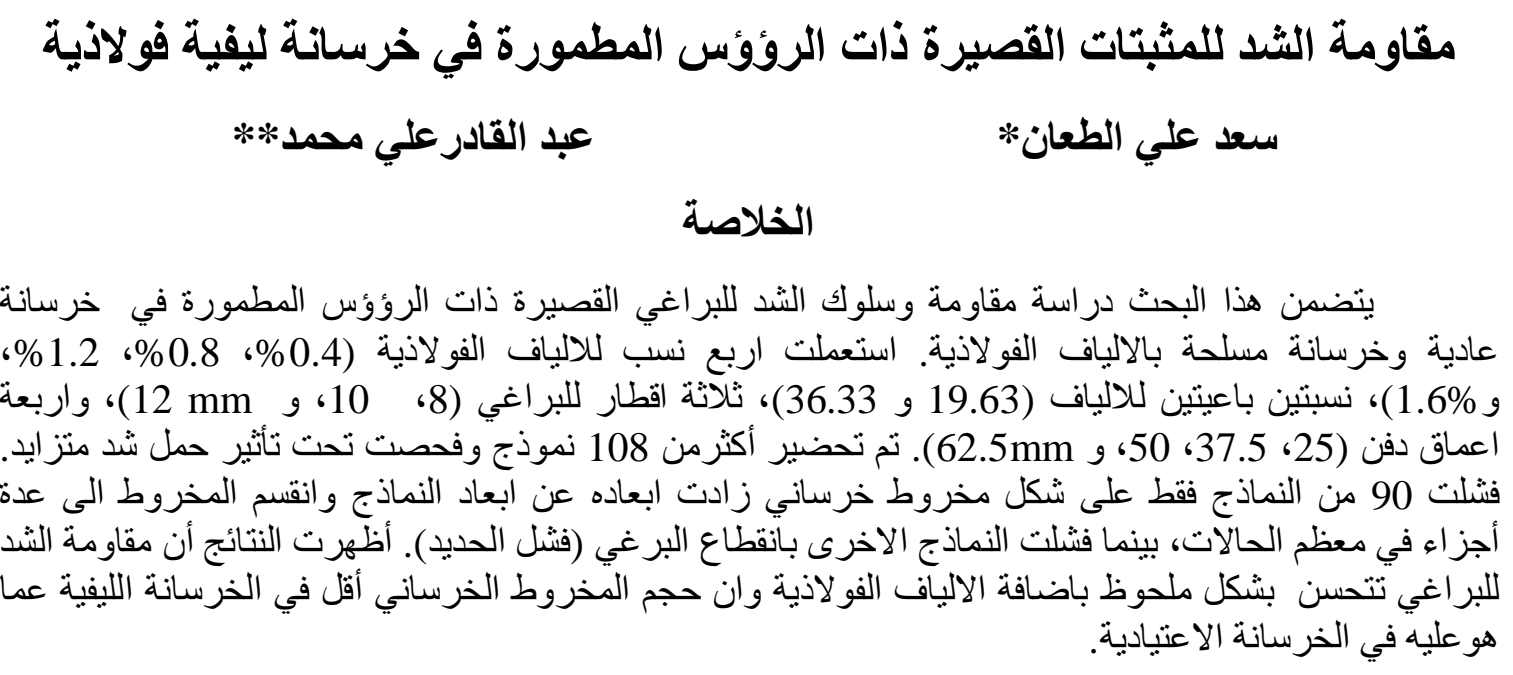

*Professor, ** Assistant lecturer, Dept. of Civil Engineering, Mosul University, Mosul, IRAQ. 


\section{INTRODUCTION}

Anchor bolts embedded in concrete are found in many kinds of structures, and are subjected to different load combinations. A short anchor bolt is usually defined as one whose embedment length is insufficient to develop tensile yield in the bolt without the end anchorage provided by the bolt head [1]. The anchors can be used for attachments of instruments, and other structural members to concrete, as well as many other uses in structural applications (precast, prestressed, etc.). Anchors can be classified according to the way of installation, namely post-installed, and cast-in-place [2,3].

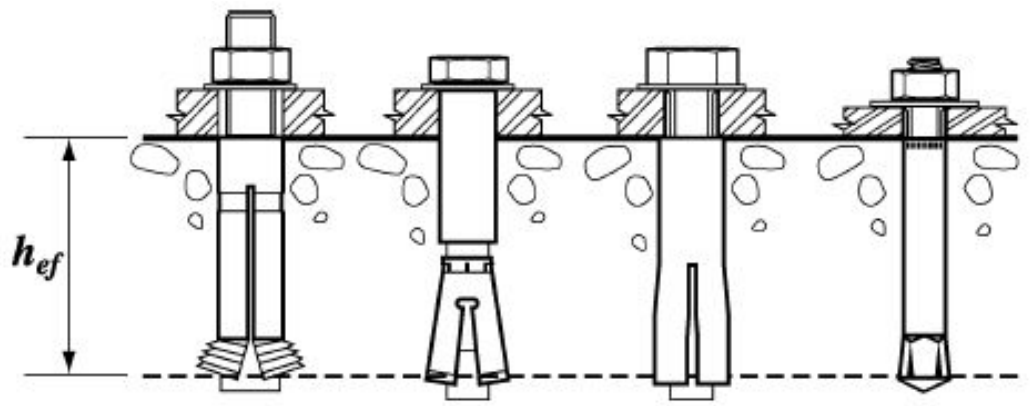

(a) Post-installed anchors

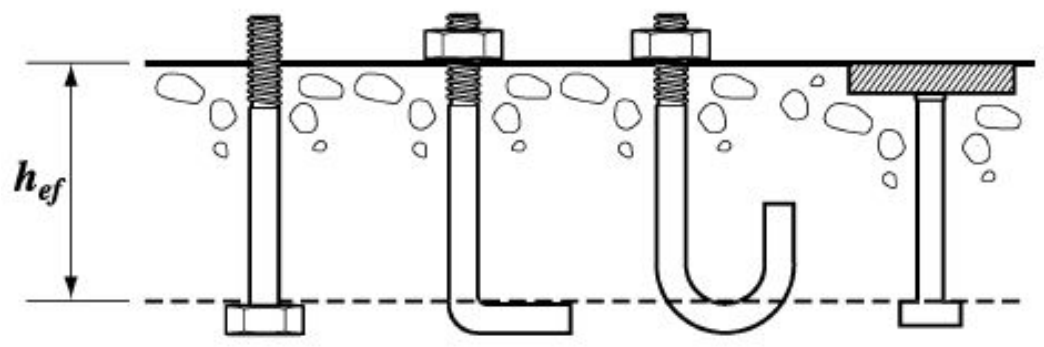

(b) Cast-in-place anchors

Fig. (1) Types of anchors, (a) Post-installed anchors, (b) Cast-in-place anchors [1]

Post-installed anchors can be fastened in almost any position desired in hardened concrete by installing them in a hole drilled after concrete hardening, and these may include expansion and undercut anchors whereby the load transfer to concrete is achieved 
by bearing against the head. Adhesive and grouted anchors which transfer loads by bond between the fastener and concrete can also be used, Fig. (1a).

Cast-in place installed systems are available for fastening to the formwork before casting the fresh concrete in the formwork, and these include headed anchor bolts, headed studs, $\mathrm{J}$ or L bolts, and undercut anchors. These anchors transfer loads to the concrete by bond (friction and mechanical interlocking) and bearing against the head, Fig. (1b).

It has been found that the pull-out capacity of short headed anchor bolts embedded in normal concrete is proportional to the tensile strength of concrete, and nonlinearly to the embedment depth of the anchor [1-4].

Addition of steel fibers to concrete improves the tensile strength, strain capacity, ductility, and fracture toughness [4,5], thus anchors behaviour and strength may be different in (SFRC) than in (NC).

\section{REASERCH SIGNIFICANCE}

The aim of this experimental programme is to study the effect of adding short discrete steel fibers on the tensile strength and behaviour of short headed anchors embedded in concrete.

\section{EXPERIMENTAL PROGRAM}

Figure (2) shows the flowchart of the experimental programme [6]. The specimens were divided into four groups depending on the embedment depth, $(25,37.5$, $50,62.5 \mathrm{~mm})$. For each group three bolt diameters were used $\left(d_{b}=8,10,12 \mathrm{~mm}\right)$. Two aspect ratios of the steel fibers were used, and for each one, five fibers volume percentages were used $\left(v_{f}=0,0.4 .0 .8,1.2,1.6\right)$. With each specimen, six cylinders $(100 \times 200 \mathrm{~mm})$ were cast; three for measuring the compressive strength and three for the splitting tensile strength.

Steel: Three diameters of the anchor bolts were used $\left(d_{b}=8,10,12 \mathrm{~mm}\right)$. Table (1) shows the engineering properties of the anchor bolts. Steel reinforcement with $(8 \mathrm{~mm})$ diameter was used to reinforce the periphery of the specimens in the longitudinal and 
circumferential directions to prevent tension failure in concrete, and bars with $(16 \mathrm{~mm})$ diameter were used to support the specimens in the test apparatus, Fig.(3).

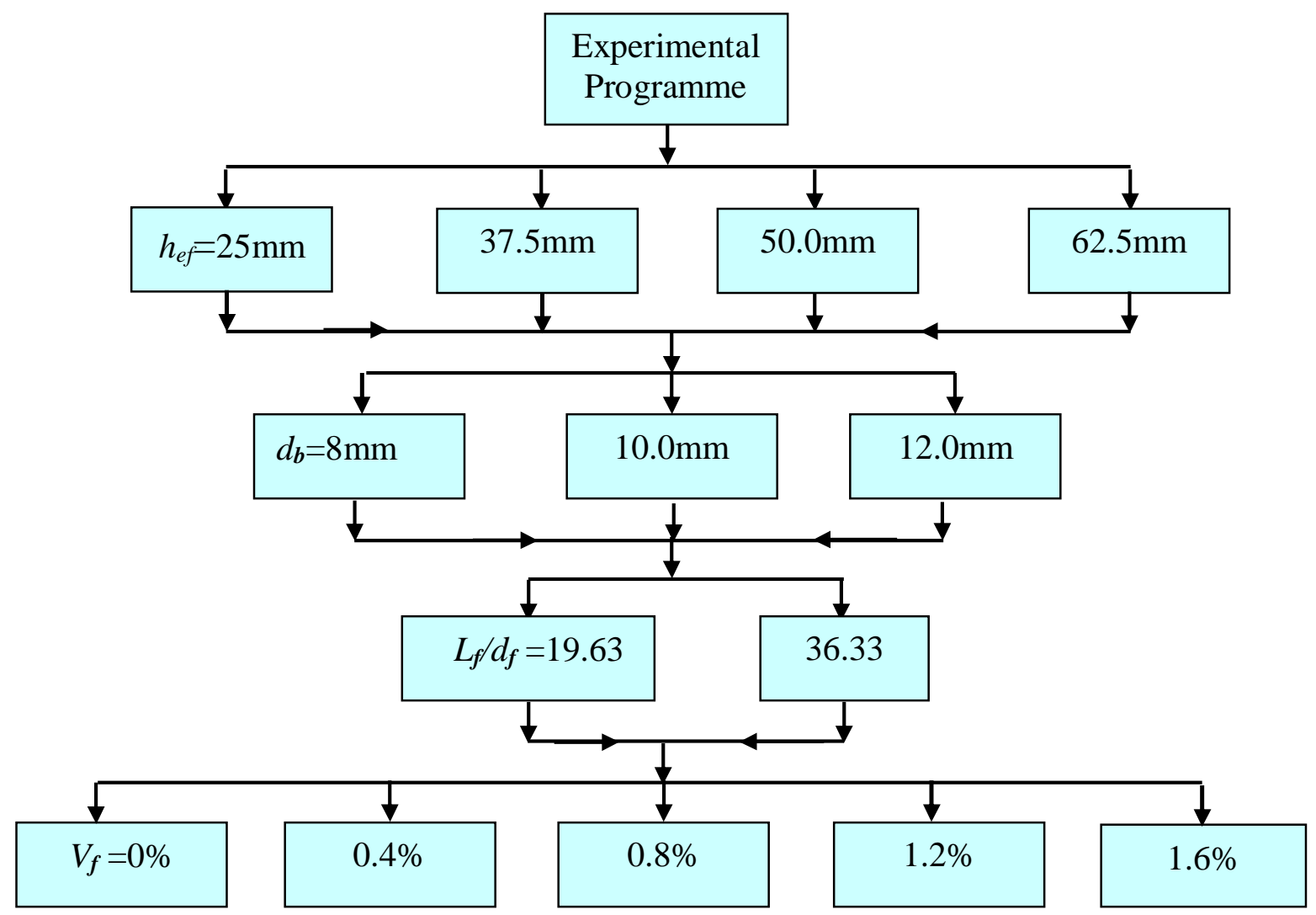

Fig.(2) Flow chart for the experimental programme

Table (1) Properties of the Anchor Bolts.

\begin{tabular}{|l|c|l|c|c|c|l|}
\hline $\begin{array}{l}\text { Material } \\
\text { Specification }\end{array}$ & $\begin{array}{l}\text { Grade } \\
\text { or Type }\end{array}$ & $\begin{array}{l}\mathrm{d}_{\mathrm{b}} \\
(\mathrm{mm})\end{array}$ & $\begin{array}{l}\text { Yield } \\
\text { Strength } \\
(\mathrm{MPa})\end{array}$ & $\begin{array}{l}\text { Tensile } \\
\text { Strength } \\
(\mathrm{MPa})\end{array}$ & $\begin{array}{l}\text { Elongation } \\
\text { Min. (mm) }\end{array}$ & $\begin{array}{l}\text { Reduction } \\
\text { of area } \\
\text { Min.(\%) }\end{array}$ \\
\hline ASTMA307 & $\mathrm{A}$ & 8 & 414 & 414 & 50.8 & \\
\hline ASTmA354 & BD & 10 & 862 & 1034 & 50.8 & 40 \\
\cline { 3 - 7 } & & 12 & 862 & 1034 & 50.8 & 40 \\
\hline
\end{tabular}


Table (2) Material properties

\begin{tabular}{|c|c|c|c|c|c|c|c|c|}
\hline Group & $\begin{array}{c}\text { Mix } \\
\text { proportion }\end{array}$ & $\begin{array}{l}\text { F.M } \\
\text { sand }\end{array}$ & $\begin{array}{c}\text { M.A.S } \\
\text { Gravel } \\
(\mathrm{mm})\end{array}$ & $\begin{array}{c}V_{f} \\
(\%)\end{array}$ & $l_{f} / d_{f}$ & $\begin{array}{l}a v \cdot f^{\prime}{ }_{c} \\
(M P a)\end{array}$ & $\begin{array}{l}a v \cdot f_{s p f} \\
(M P a)\end{array}$ & $\begin{array}{c}\text { No. of } \\
\text { samples }\end{array}$ \\
\hline $\mathrm{NC}$ & $1: 1.7: 3.5 / 0.45$ & 2.91 & 10 & 0 & --- & 30.0 & 2.82 & $6^{*}$ \\
\hline *SFRC0.4 & $1: 1.7: 3.5 / 0.45$ & 2.91 & 10 & 0.4 & 19.63 & 32.2 & 3.11 & 6 \\
\hline SFRC0.8 & $1: 1.7: 3.5 / 0.45$ & 2.91 & 10 & 0.8 & 19.63 & 33.0 & 3.67 & 6 \\
\hline SFRC1.2 & $1: 1.7: 3.5 / 0.45$ & 2.91 & 10 & 1.2 & 19.63 & 34.0 & 3.38 & 6 \\
\hline SFRC1.6 & $1: 1.7: 3.5 / 0.45$ & 2.91 & 10 & 1.6 & 19.63 & 35.1 & 3.58 & 6 \\
\hline SFRC0.4 & $1: 1.7: 3.5 / 0.45$ & 2.91 & 10 & 0.4 & 36.33 & 33.0 & 3.27 & 6 \\
\hline SFRC0.8 & $1: 1.7: 3.5 / 0.45$ & 2.91 & 10 & 0.8 & 36.33 & 33.7 & 3.44 & 6 \\
\hline SFRC1.2 & $1: 1.7: 3.5 / 0.45$ & 2.91 & 10 & 1.2 & 36.33 & 35.5 & 3.57 & 6 \\
\hline SFRC1.6 & $1: 1.7: 3.5 / 0.45$ & 2.91 & 10 & 1.6 & 36.33 & 36.3 & 3.68 & 6 \\
\hline
\end{tabular}

Concrete: Concrete mix proportions was (1:1.7:3.5/0.45), Ordinary Portland Cement, medium size sand with a fineness modulus (2.91), and gravel with maximum aggregate size $(10 \mathrm{~mm})$ and water/cement ratio of $(0.45)$. The proportions were chosen to produce a concrete compressive strength of (30MPa) and a slump of $(100 \mathrm{~mm})$. Harex shelled steel fibers with deformed cross section with lengths $\left(l_{f}=16\right.$, and $\left.32 \mathrm{~mm}\right)$ were used which gives aspect ratio of $\left(l_{f} / d_{f}=19.63,36.33\right)$ respectively. As shown in table (2).

Volume fraction of the steel fibers $\left(v_{f}=0.4 \% .0 .8 \%, 1.2 \%, 1.6 \%\right)$ were chosen to avoid balling, and segregation and to get good workable mixes.

The dry materials were mixed first, water then added and the mixing procedure continues till the mix becomes homogeneous and the fibers then fed into the mixer gradually and the mixing procedure continues until the mix becomes homogeneous. The specimens were cast together with the six cylinders and placed on the vibrating table to get a thorough compaction. After casting and vibration, all the specimens were covered with a polythene sheet for 24 hours after which the specimens were stripped from the molds and kept in a water tank and cured for 28 days, till the time of testing at the same age.

\section{TEST PROCEDURE}

The apparatus for the pullout test is illustrated in Fig.(4). The test specimen was fixed to the lower end of the test apparatus by the $(16 \mathrm{~mm})$ bar protruding from the bottom 
of the specimens. The anchor bolt was connected to the top moving part of the frame apparatus (free surface testing). After placing the specimen in the test apparatus the pullout load was applied through approximately a constant rate to prevent any dynamic effect during the test [6]. Each bolt was tested monotonically in tension until failure occurs.

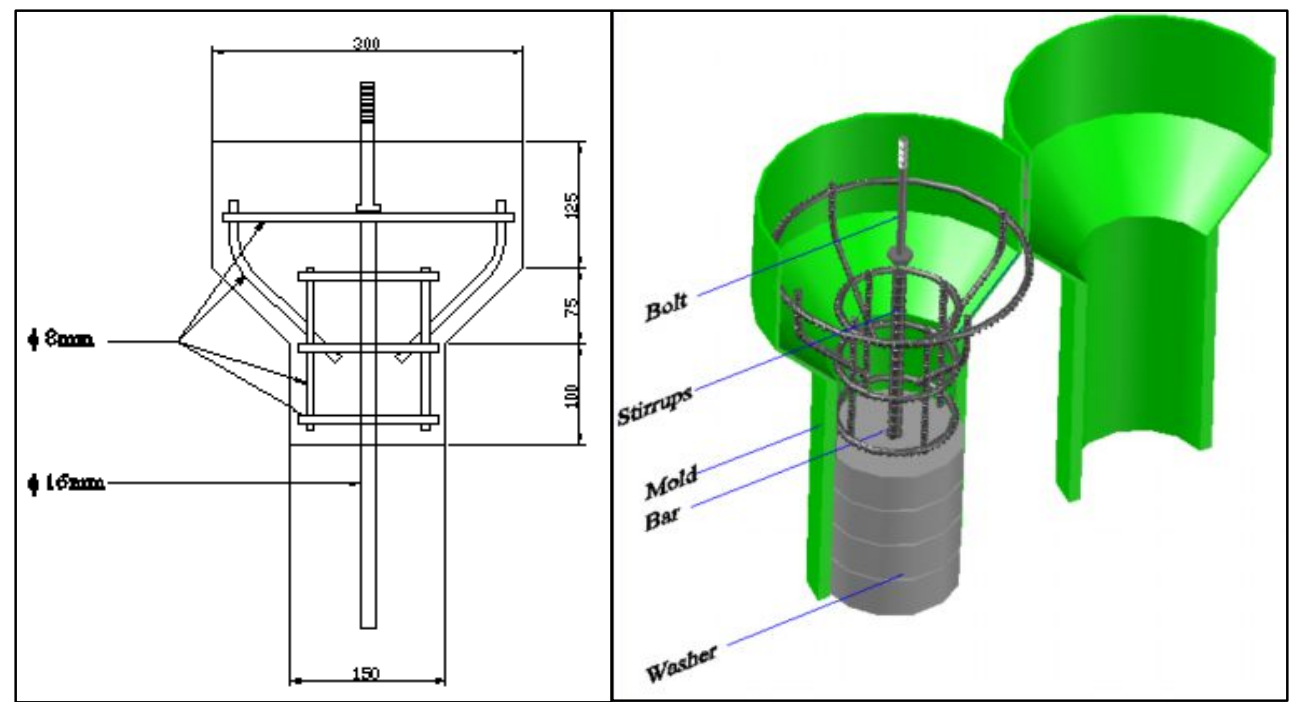

Fig. (3) Anchorage specimen, (a) Sectional view, (b Three dimensional view.

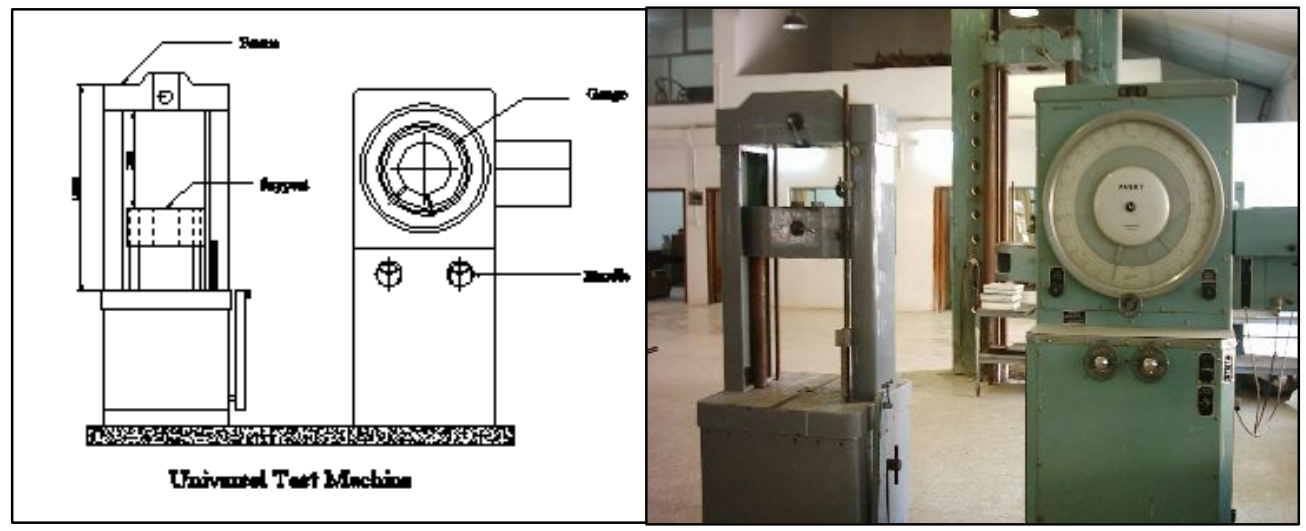

Fig. (4) Test apparatus (Universal Testing Machine).

\section{TEST RESULTS AND DISCUSSION}

All the test results are summarized in Table (2). To study the behaviour of headed anchor bolt in tension some parameters will be discussed, such as failure mode, 
effect of the embedment depth, effect of steel fibers volume percentage, and the effect of concrete strength.

Failure mode: Three failure modes were noticed, Fig. (5); (a) the failure shape in (NC) was large concrete failure cone of non uniform shape exceeded the dimensions of the specimen and the cone breaks into pieces in some cases. The angle of the cone ranged between $\left(20-33^{\circ}\right)$. (b) For (SFRC), the failure of the samples having different volume fractions is the same as that for normal concrete, but the concrete failure cone was smaller compared with the cone size in normal concrete, and in the majority of the cases the concrete failure cone was divided into four pieces, such that the angle of failure cannot be easily measured
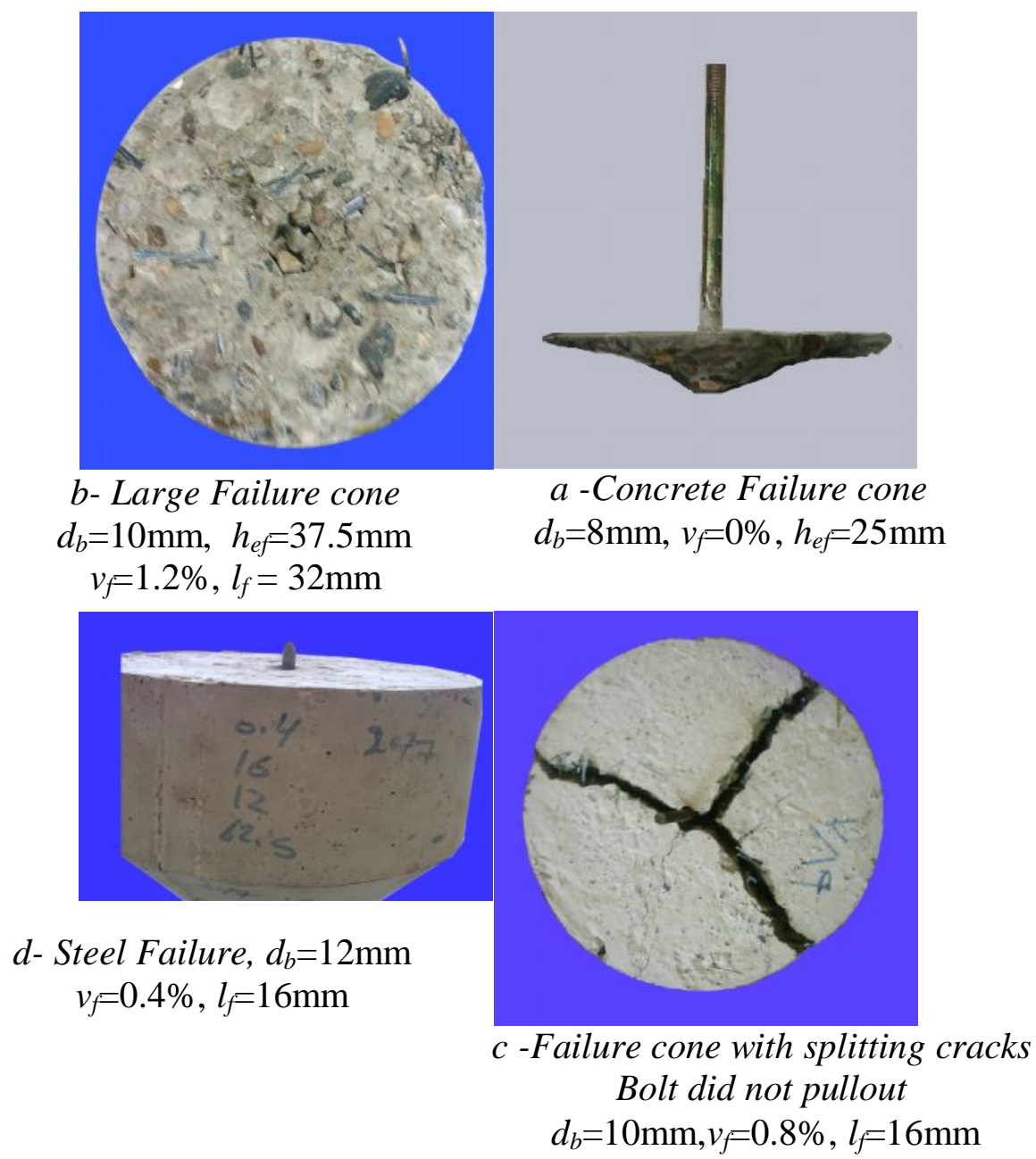

Fig.(5) Typical failure types after test: (a) normal concrete; (b-d) steel fibre Reinforced concrete. 
(c) In some cases the failure occurred by splitting cracks on the surface of the specimen, but the bolt did not pullout from the concrete because some fibers remained bonded to the concrete near the head of the anchor and prevented pullout anchor bolt. In some cases the anchor bolts was pulled out from the concrete and some pieces of the cone still connected to the specimen, specially for long fibers $\left(l_{f} / d_{f}=36.33\right)$. (d) The last mode of failure was yielding and fractures of bolts (steel failure) before pullout of the bolt occur. These cases were excluded from the test results.

Effect of embedment depth: The embedment depth is the main factor influencing the breakout capacity of the different types of anchors [3, 8, and 9]. Fig. (6) Shows the nonlinear increase of breakout capacity with the embedment depth.

When $\left(h_{e f}\right)$ increase, the dimensions of the specimen must be increased to at least $\left(6 h_{e f} \times 6 h_{e f}\right)$ to avoid the edge effect $[9,10]$ and the corresponding decrease in the breakout capacity. Angle of failure $(\theta)$ decreases when $\left(h_{e f}\right)$ increase $[1,8]$, and the volume of the cone increase when $\left(h_{e f}\right)$ increase also $[1,4,8]$. For short embedment depth, the concrete strength appeared to be more effective mainly because shallow anchors failed generally via concrete cone breakout. As the anchor embedment depth was increased, however, this beneficial effect was reduced due to shifting of failure mode of the anchors from concrete failure cone to pullout or steel failure [9].

For $\left(h_{e f}=62.5 \mathrm{~mm}\right)$ the amount of increase in the breakout capacity is higher than the others embedment depth $\left(h_{e f}=25,37.5,50 \mathrm{~mm}\right)$ because the compressive strength was more than (30MPa) and in some specimens it was up to (40MPa) or more.

Effect of steel fibers: Addition of steel fibers to concrete improves the compressive strength to some extent and the tensile strength to a greater extent. From the test results of the control specimens the increase in the compressive strength for mixes with short fibers $\left(l_{f} / d_{f}=19.63\right)$ was $(6,8,12,15.0 \%)$ for $\left(v_{f}=0.4,0.8,1.2,1.6 \%\right)$ respectively, and the corresponding increase in the splitting tensile strength was (10, 16, 20, 27\%). For mixes with long fibers $\left(l_{f} / d_{f}=36.33\right)$ the increase in the compressive strength was $(8,11,16$, 
$19 \%)$ for $\left(v_{f}=0.4,0.8,1.2,1.6 \%\right)$ respectively, and the corresponding increase in the splitting tensile strength was $(16,22,27,31 \%)$. It can be noticed from the pervious results that the increase in the tensile strength for mixes with the long fibers is more than that for mixes with short fibers due to the longer anchorage length [10-12].

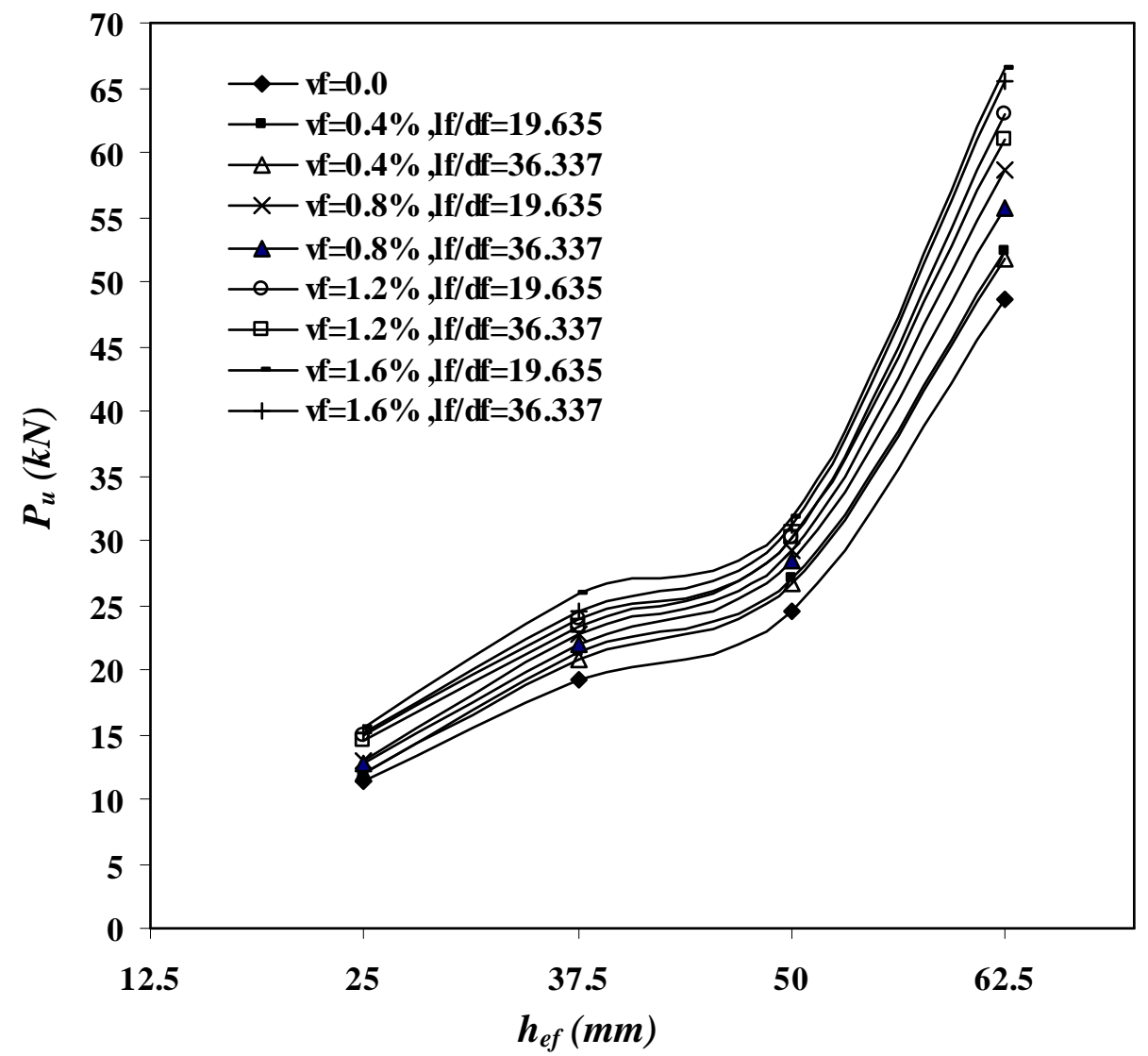

Fig. (6) Variation of observed breakout capacity $\left(P_{u}\right)$ with embedment $\operatorname{depth}\left(h_{e f}\right)$.

As shown in Fig. (7), the breakout capacity increased significantly with the volume fraction of steel fibers. The Figure shows that the amount of increase in the breakout capacity for anchor bolts embedded in (SFRC) with short steel fiber $\left(l_{f} / d_{f}=19.63\right)$ was greater than for long fiber $\left(l_{f} / d_{f}=36.33\right)$. This may be attributed to the fact that the distribution of short fibers in concrete mixes is better than for mixes with long fibers, and for the same volume fraction the number of fibers per unit volume of the matrix are more and the spacing are less between short fibers than those for long fibers $[1,9,11]$. In some cases the difference in breakout capacity values between the two types of fibers was small as shown in Fig.(7). 


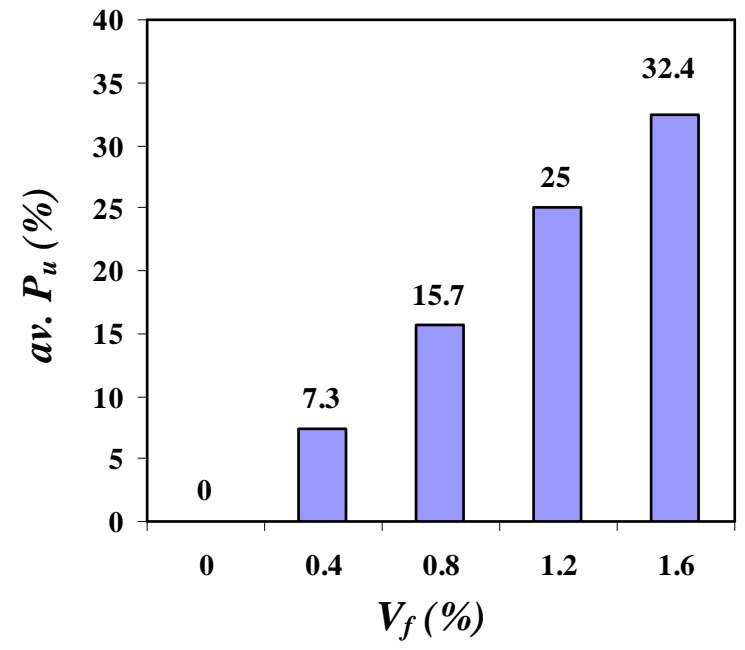

(a)- Average increase in $\left(P_{u}\right)$ with volume fraction of steel fibers $\left(V_{f}\right)$.
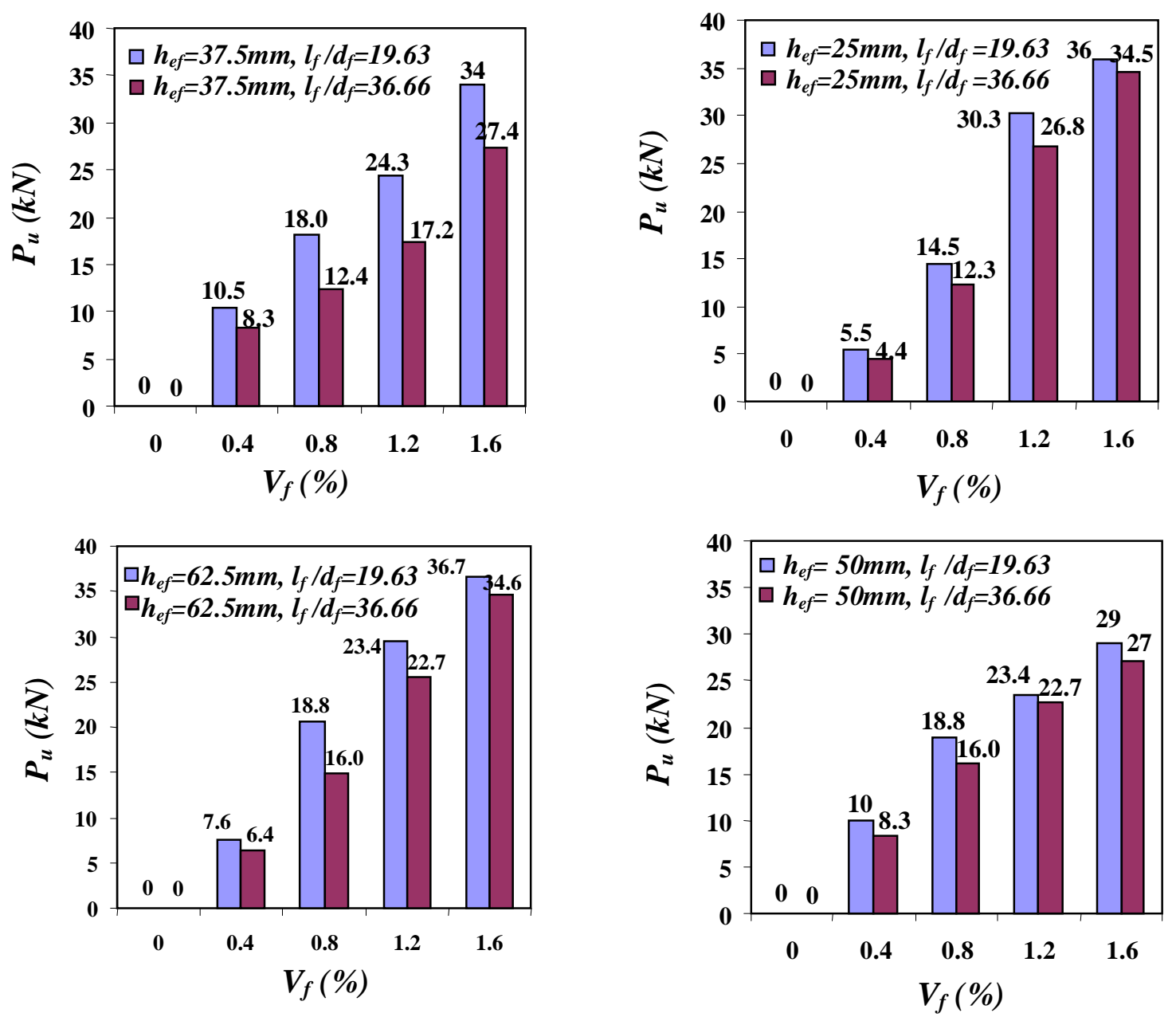

(b)- Variation of observed breakout capacity $\left(P_{u}\right)$ with volume fraction of steel fiber $\left(V_{f} \%\right)$

Fig. (7 )Effect of steel fibers on breakout capacity $\left(P_{u}\right),(a)$ Amount of increase, (b) Variation with steel fiber. 
Effect of concrete strength: Generally the anchor capacity increased with the tensile strength of concrete, and the latter increased with the concrete strength $[2,13,14]$, even though the increment is not uniform for some cases. Steel fibers enhance the concrete strength, especially the tensile strength depending on the mechanical interlock between the steel fibers and concrete, and the pullout strength of steel fibers. Fig. (8) shows the variation in the anchor capacity with the concrete strength.
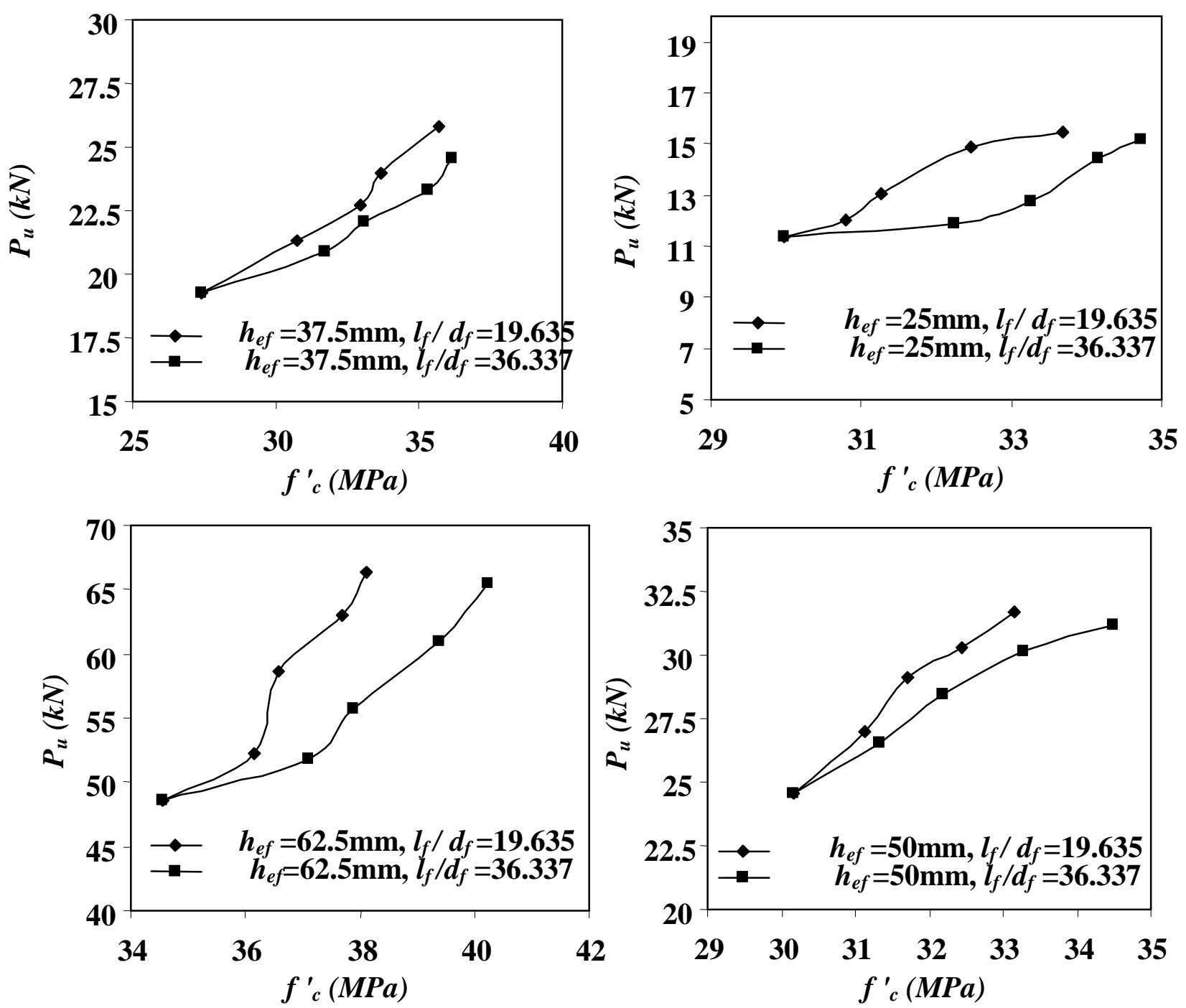

Fig.(8) Variation of the failure load with the compressive strength of concrete. 
Al- Ta'an: Tensile Strength of Short Headed Anchors Embedded in Steel Fibrous ...

Table (2) Test results

\begin{tabular}{|c|c|c|c|c|c|c|c|c|}
\hline No. & $\overline{\text { Group }}$ & $\begin{array}{c}\mathbf{h}_{\text {ef }} \\
(\mathbf{m m})\end{array}$ & $\begin{array}{l}\mathbf{v}_{\mathbf{f}} \\
(\%)\end{array}$ & $\mathbf{l}_{\mathrm{f}} / \mathbf{d}_{\mathbf{f}}$ & $\begin{array}{c}\mathbf{d}_{\mathbf{b}} \\
(\mathbf{m m})\end{array}$ & $\begin{array}{c}f_{c}^{\prime} \\
(\boldsymbol{M P a})\end{array}$ & $\begin{array}{c}f_{s p f} \\
(M P a)\end{array}$ & $\begin{array}{l}\mathbf{P}_{\text {test }} \\
(\mathbf{k N})\end{array}$ \\
\hline 1 & NC & 25 & $\mathbf{0}$ & $\mathbf{0}$ & 8 & 30.0 & 2.49 & 11.278 \\
\hline 2 & NC & 25 & $\mathbf{0}$ & $\mathbf{0}$ & 10 & 30.0 & 2.49 & 11.376 \\
\hline 3 & $\mathbf{N C}$ & 25 & $\mathbf{0}$ & $\mathbf{0}$ & 12 & 30.0 & 2.49 & 11474 \\
\hline 4 & SFRC0.4 & 25 & 0.4 & 19.63 & 8 & 30.8 & 2.97 & 11.768 \\
\hline 5 & SFRC0.4 & 25 & 0.4 & 19.63 & 10 & 30.8 & 2.97 & 12.013 \\
\hline 6 & SFRC0.4 & 25 & 0.4 & 19.63 & 12 & 30.8 & 2.97 & 12.258 \\
\hline 7 & SFRC0.8 & 25 & 0.8 & 19.63 & 8 & 31.2 & 3.12 & 12.602 \\
\hline 8 & SFRC0.8 & 25 & 0.8 & 19.63 & 10 & 31.2 & 3.12 & 12.945 \\
\hline 9 & SFRC0.8 & 25 & 0.8 & 19.63 & 12 & 31.2 & 3.12 & $\mathbf{1 3 . 5 3 3}$ \\
\hline 10 & SFRC1.2 & 25 & 1.2 & 19.63 & 8 & 32.4 & 3.22 & 14.465 \\
\hline 11 & SFRC1.2 & 25 & 1.2 & 19.63 & 10 & 32.4 & 3.22 & 14.710 \\
\hline 12 & SFRC1.2 & 25 & 1.2 & 19.63 & 12 & 32.4 & 3.22 & 15.298 \\
\hline 13 & SFRC1.6 & 25 & 1.6 & 19.63 & 8 & 33.6 & 3.55 & 15.325 \\
\hline 14 & SFRC1.6 & 25 & 1.6 & 19.63 & 10 & 33.6 & 3.55 & 15.446 \\
\hline 15 & SFRC1.6 & 25 & 1.6 & 19.63 & 12 & 33.6 & 3.55 & 15.642 \\
\hline 16 & SFRC0.4 & 25 & 0.4 & 36.33 & 8 & 32.2 & 3.21 & 11.670 \\
\hline 17 & SFRC0.4 & 25 & 0.4 & 36.33 & 10 & 32.2 & 3.21 & 11.866 \\
\hline 18 & SFRC0.4 & 25 & 0.4 & 36.33 & 12 & 32.2 & 3.21 & 12.097 \\
\hline 19 & SFRC0.8 & 25 & 0.8 & 36.33 & 8 & 32.3 & 3.35 & 12.223 \\
\hline 20 & SFRC0.8 & 25 & 0.8 & 36.33 & 10 & 32.3 & 3.35 & 12.800 \\
\hline 21 & SFRC0.8 & 25 & 0.8 & 36.33 & 12 & 32.3 & 3.35 & 13.310 \\
\hline 22 & SFRC1.2 & 25 & 1.2 & 36.33 & 8 & 34.1 & 3.44 & 13.730 \\
\hline 23 & SFRC1.2 & 25 & 1.2 & 36.33 & 10 & 34.1 & 3.44 & 14.563 \\
\hline 24 & SFRC1.2 & 25 & 1.2 & 36.33 & 12 & 34.1 & 3.44 & 14.980 \\
\hline 25 & SFRC1.6 & 25 & 1.6 & 36.33 & 8 & 34.7 & 3.57 & 15.050 \\
\hline 26 & SFRC1.6 & 25 & 1.6 & 36.33 & 10 & 34.7 & 3.57 & 15.170 \\
\hline 27 & SFRC1.6 & 25 & 1.6 & 36.33 & 12 & 34.7 & 3.57 & 15.290 \\
\hline 28 & $\mathrm{NC}$ & 37.5 & $\mathbf{0}$ & $\mathbf{0}$ & 8 & 27.4 & 2.48 & 18.926 \\
\hline 29 & NC & 37.5 & $\mathbf{0}$ & $\mathbf{0}$ & 10 & 27.4 & 2.48 & 19.240 \\
\hline 30 & NC & 37.5 & $\mathbf{0}$ & $\mathbf{0}$ & 12 & 27.4 & 2.48 & 19.654 \\
\hline 31 & SFRC0.4 & 37.5 & 0.4 & 19.63 & 8 & 30.7 & 2.83 & 20.775 \\
\hline 32 & SFRC0.4 & 37.5 & 0.4 & 19.63 & 10 & 30.7 & 2.83 & 21.304 \\
\hline 33 & SFRC0.4 & 37.5 & 0.4 & 19.63 & 12 & 30.7 & 2.83 & 21.832 \\
\hline 34 & SFRC0.8 & 37.5 & 0.8 & 19.63 & 8 & 32.9 & 3.16 & 22.316 \\
\hline 35 & SFRC0.8 & 37.5 & 0.8 & 19.63 & 10 & 32.9 & 3.16 & 22.875 \\
\hline 36 & SFRC0.8 & 37.5 & 0.8 & 19.63 & 12 & 32.9 & 3.16 & 23.065 \\
\hline 37 & SFRC1.2 & 37.5 & 1.2 & 19.63 & 8 & 33.6 & 3.34 & 23.677 \\
\hline 38 & SFRC1.2 & 37.5 & 1.2 & 19.63 & $\mathbf{1 0}$ & 33.6 & 3.34 & 23.987 \\
\hline 39 & SFRC1.2 & 37.5 & 1.2 & 19.63 & 12 & 33.6 & 3.34 & 24.251 \\
\hline 40 & SFRC1.6 & 37.5 & 1.6 & 19.63 & 8 & 35.7 & 3.49 & 25.068 \\
\hline 41 & SFRC1.6 & 37.5 & 1.6 & 19.63 & 10 & 35.7 & 3.49 & 25.887 \\
\hline 42 & SFRC1.6 & 37.5 & 1.6 & 19.63 & 12 & 35.7 & 3.49 & 26.571 \\
\hline 43 & SFRC0.4 & 37.5 & 0.4 & 36.33 & 8 & 31.5 & 2.94 & 20.256 \\
\hline 44 & SFRC0.4 & 37.5 & 0.4 & 36.33 & 10 & 31.5 & 2.94 & 20.937 \\
\hline 45 & SFRC0.4 & 37.5 & 0.4 & 36.33 & 12 & 31.5 & 2.94 & 21.447 \\
\hline
\end{tabular}


Al- Ta'an: Tensile Strength of Short Headed Anchors Embedded in Steel Fibrous ...

\begin{tabular}{|c|c|c|c|c|c|c|c|c|}
\hline 46 & SFRC0.8 & 37.5 & 0.8 & 36.33 & 8 & 33.0 & 3.32 & 21.625 \\
\hline 47 & SFRC0.8 & 37.5 & 0.8 & 36.33 & 10 & 33.0 & 3.32 & 21.975 \\
\hline 48 & SFRC0.8 & 37.5 & 0.8 & 36.33 & 12 & 33.0 & 3.32 & 22.565 \\
\hline 49 & SFRC1.2 & 37.5 & 1.2 & 36.33 & 8 & 35.3 & 3.51 & 22.876 \\
\hline 50 & SFRC1.2 & 37.5 & 1.2 & 36.33 & 10 & 35.3 & 3.51 & 23.256 \\
\hline 51 & SFRC1.2 & 37.5 & 1.2 & 36.33 & 12 & 35.3 & 3.51 & 23.768 \\
\hline 52 & SFRC1.6 & 37.5 & 1.6 & 36.33 & 8 & 36.1 & 3.56 & 24.125 \\
\hline 53 & SFRC1.6 & 37.5 & 1.6 & 36.33 & 10 & 36.1 & 3.56 & 24.563 \\
\hline 54 & SFRC1.6 & 37.5 & 1.6 & 36.33 & 12 & 36.1 & 3.56 & 25.000 \\
\hline 55 & $\mathrm{NC}$ & 50 & $\mathbf{0}$ & $\mathbf{0}$ & 8 & 30.1 & 2.79 & 24.419 \\
\hline 56 & $\mathrm{NC}$ & 50 & $\mathbf{0}$ & $\mathbf{0}$ & 10 & 30.1 & 2.79 & 24.517 \\
\hline 57 & $\mathrm{NC}$ & 50 & 0 & $\mathbf{0}$ & 12 & 30.1 & 2.79 & 24.664 \\
\hline 58 & SFRC0.4 & 50 & 0.4 & 19.63 & 8 & 31.1 & 3.01 & $* * *$ \\
\hline 59 & SFRC0.4 & 50 & 0.4 & 19.63 & 10 & 31.1 & 3.01 & 26.871 \\
\hline 60 & SFRC0.4 & 50 & 0.4 & 19.63 & 12 & 31.1 & 3.01 & 27.145 \\
\hline 61 & SFRC0.8 & 50 & 0.8 & 19.63 & 8 & 31.7 & 3.11 & $* * *$ \\
\hline 62 & SFRC0.8 & 50 & 0.8 & 19.63 & 10 & 31.7 & 3.11 & 28.930 \\
\hline 63 & SFRC0.8 & 50 & 0.8 & 19.63 & 12 & 31.7 & 3.11 & 29.372 \\
\hline 64 & SFRC1.2 & 50 & 1.2 & 19.63 & 8 & 32.4 & 3.20 & $* * *$ \\
\hline 65 & SFRC1.2 & 50 & 1.2 & 19.63 & 10 & 32.4 & 3.20 & 30.166 \\
\hline 66 & SFRC1.2 & 50 & 1.2 & 19.63 & 12 & 32.4 & 3.20 & 30.400 \\
\hline 67 & SFRC1.6 & 50 & 1.6 & 19.63 & 8 & 33.1 & 3.46 & $* * *$ \\
\hline 68 & SFRC1.6 & 50 & 1.6 & 19.63 & 10 & 33.1 & 3.46 & 31.530 \\
\hline 69 & SFRC1.6 & 50 & 1.6 & 19.63 & 12 & 33.1 & 3.46 & 31.804 \\
\hline 70 & SFRC0.4 & 50 & 0.4 & 36.33 & 8 & 31.3 & 3.20 & 26.135 \\
\hline 71 & SFRC0.4 & 50 & 0.4 & 36.33 & 10 & 31.3 & 3.20 & 26.538 \\
\hline 72 & SFRC0.4 & 50 & 0.4 & 36.33 & 12 & 31.3 & 3.20 & 27.060 \\
\hline 73 & SFRC0.8 & 50 & 0.8 & 36.33 & 8 & 32.1 & 3.33 & $* * *$ \\
\hline 74 & SFRC0.8 & 50 & 0.8 & 36.33 & 10 & 32.1 & 3.33 & 28.342 \\
\hline 75 & SFRC0.8 & 50 & 0.8 & 36.33 & 12 & 32.1 & 3.33 & 28.587 \\
\hline 76 & SFRC1.2 & 50 & 1.2 & 36.33 & 8 & 33.2 & 3.41 & $* * *$ \\
\hline 77 & SFRC1.2 & 50 & 1.2 & 36.33 & 10 & 33.2 & 3.41 & 29.975 \\
\hline 78 & SFRC1.2 & 50 & 1.2 & 36.33 & 12 & 33.2 & 3.41 & 30.264 \\
\hline 79 & SFRC1.6 & 50 & 1.6 & 36.33 & 8 & 34.4 & 3.55 & $* * *$ \\
\hline 80 & SFRC1.6 & 50 & 1.6 & 36.33 & 10 & 34.4 & 3.55 & 30.940 \\
\hline 81 & SFRC1.6 & 50 & 1.6 & 36.33 & 12 & 34.4 & 3.55 & 31.382 \\
\hline 82 & NC & 62.5 & $\mathbf{0}$ & 0 & 8 & 34.5 & 3.35 & $* * *$ \\
\hline 83 & $\mathrm{NC}$ & 62.5 & $\mathbf{0}$ & $\mathbf{0}$ & 10 & 34.5 & 3.35 & 48.277 \\
\hline 84 & NC & 62.5 & $\mathbf{0}$ & $\mathbf{0}$ & 12 & 34.5 & 3.35 & 48.885 \\
\hline 85 & SFRC0.4 & 62.5 & 0.4 & 19.63 & 8 & 36.1 & 3.61 & $* * *$ \\
\hline 86 & SFRC0.4 & 62.5 & 0.4 & 19.63 & 10 & 36.1 & 3.61 & $\mathbf{5 2 . 2 8 5}$ \\
\hline 87 & SFRC0.4 & 62.5 & 0.4 & 19.63 & 12 & 36.1 & 3.61 & $* * *$ \\
\hline 88 & SFRC0.8 & 62.5 & 0.8 & 19.63 & 8 & 36.5 & 3.68 & $* * *$ \\
\hline 89 & SFRC0.8 & 62.5 & 0.8 & 19.63 & 10 & 36.5 & 3.68 & $* * *$ \\
\hline 90 & SFRC0.8 & 62.5 & 0.8 & 19.63 & 12 & 36.5 & 3.68 & $\mathbf{5 8 . 5 7 7}$ \\
\hline 91 & SFRC1.2 & 62.5 & 1.2 & 19.63 & 8 & 37.6 & 3.77 & $* * *$ \\
\hline 92 & SFRC1.2 & 62.5 & 1.2 & 19.63 & 10 & 37.6 & 3.77 & 62.435 \\
\hline 93 & SFRC1.2 & 62.5 & 1.2 & 19.63 & 12 & 37.6 & 3.77 & 63.481 \\
\hline 94 & SFRC1.6 & 62.5 & 1.6 & 19.63 & 8 & 38.1 & 3.84 & $* * *$ \\
\hline
\end{tabular}




\begin{tabular}{||c|c|c|c|c|c|c|c|c|}
\hline 95 & SFRC1.6 & $\mathbf{6 2 . 5}$ & $\mathbf{1 . 6}$ & $\mathbf{1 9 . 6 3}$ & $\mathbf{1 0}$ & $\mathbf{3 8 . 1}$ & $\mathbf{3 . 8 4}$ & $\mathbf{6 6 . 3 6 4}$ \\
\hline 96 & SFRC1.6 & $\mathbf{6 2 . 5}$ & $\mathbf{1 . 6}$ & $\mathbf{1 9 . 6 3}$ & $\mathbf{1 2}$ & $\mathbf{3 8 . 1}$ & $\mathbf{3 . 8 4}$ & $\mathbf{6 6 . 4 9 1}$ \\
\hline 97 & SFRC0.4 & $\mathbf{6 2 . 5}$ & $\mathbf{0 . 4}$ & $\mathbf{3 6 . 3 3}$ & $\mathbf{8}$ & $\mathbf{3 7 . 0}$ & $\mathbf{3 . 7 4}$ & $* * *$ \\
\hline 98 & SFRC0.4 & $\mathbf{6 2 . 5}$ & $\mathbf{0 . 4}$ & $\mathbf{3 6 . 3 3}$ & $\mathbf{1 0}$ & $\mathbf{3 7 . 0}$ & $\mathbf{3 . 7 4}$ & $\mathbf{5 1 . 5 8 7}$ \\
\hline 99 & SFRC0.4 & $\mathbf{6 2 . 5}$ & $\mathbf{0 . 4}$ & $\mathbf{3 6 . 3 3}$ & $\mathbf{1 2}$ & $\mathbf{3 7 . 0}$ & $\mathbf{3 . 7 4}$ & $\mathbf{5 1 . 8 6 3}$ \\
\hline 100 & SFRC0.8 & $\mathbf{6 2 . 5}$ & $\mathbf{0 . 8}$ & $\mathbf{3 6 . 3 3}$ & $\mathbf{8}$ & $\mathbf{3 7 . 8}$ & $\mathbf{3 . 7 8}$ & $* * *$ \\
\hline 101 & SFRC0.8 & $\mathbf{6 2 . 5}$ & $\mathbf{0 . 8}$ & $\mathbf{3 6 . 3 3}$ & $\mathbf{1 0}$ & $\mathbf{3 7 . 8}$ & $\mathbf{3 . 7 8}$ & $\mathbf{5 5 . 4 7 9}$ \\
\hline 102 & SFRC0.8 & $\mathbf{6 2 . 5}$ & $\mathbf{0 . 8}$ & $\mathbf{3 6 . 3 3}$ & $\mathbf{1 2}$ & $\mathbf{3 7 . 8}$ & $\mathbf{3 . 7 8}$ & $\mathbf{5 6 . 0 4 8}$ \\
\hline 103 & SFRC1.2 & $\mathbf{6 2 . 5}$ & 1.2 & $\mathbf{3 6 . 3 3}$ & $\mathbf{8}$ & $\mathbf{3 9 . 3}$ & $\mathbf{3 . 9 2}$ & $* * *$ \\
\hline 104 & SFRC1.2 & $\mathbf{6 2 . 5}$ & $\mathbf{1 . 2}$ & $\mathbf{3 6 . 3 3}$ & $\mathbf{1 0}$ & $\mathbf{3 9 . 3}$ & $\mathbf{3 . 9 2}$ & $\mathbf{6 0 . 4 7 5}$ \\
\hline 105 & SFRC1.2 & $\mathbf{6 2 . 5}$ & 1.2 & $\mathbf{3 6 . 3 3}$ & $\mathbf{1 2}$ & $\mathbf{3 9 . 3}$ & $\mathbf{3 . 9 2}$ & $\mathbf{6 1 . 4 9 6}$ \\
\hline 106 & SFRC1.6 & $\mathbf{6 2 . 5}$ & $\mathbf{1 . 6}$ & $\mathbf{3 6 . 3 3}$ & $\mathbf{8}$ & $\mathbf{4 0 . 2}$ & $\mathbf{4 . 0 5}$ & $* * *$ \\
\hline 107 & SFRC1.6 & $\mathbf{6 2 . 5}$ & 1.6 & $\mathbf{3 6 . 3 3}$ & 10 & $\mathbf{4 0 . 2}$ & $\mathbf{4 . 0 5}$ & $\mathbf{6 5 . 1 6 7}$ \\
\hline 108 & SFRC1.6 & $\mathbf{6 2 . 5}$ & 1.6 & $\mathbf{3 6 . 3 3}$ & $\mathbf{1 2}$ & $\mathbf{4 0 . 2}$ & $\mathbf{4 . 0 5}$ & $\mathbf{6 5 . 6 8 7}$ \\
\hline \hline
\end{tabular}

$* * *$ Steel failure

\section{CONCLUSIONS}

The breakout capacity of headed anchor bolts embedded in concrete increased almost linearly with the volume fraction of the added steel fibers by up to $32 \%$. The increase in the breakout capacity was found to be more for short fibers than for long fibers. The volume of the failure concrete cone for headed bolts embedded in fibrous concrete is less than that for headed bolts embedded in plain or unreinforced concrete. More experimental results are required to verify these findings and to develop a method for predicting the breakout capacity of headed bolts embedded in fibrous concrete.

\section{NOTATIONS}

$\begin{array}{ll}v_{f} & \text { Volume fraction of steel fibers }(\%) \\ l_{f} / d_{f} & \text { Aspect ratio (fiber length/fiber diameter) } \\ d_{b} & \text { diameter of bolt }(\mathrm{mm}) \\ h_{e f} & \text { Embedment depth }(\mathrm{mm}) \\ P_{u} & \text { Observed breakout capacity (Failure load) } \\ f_{c}^{\prime} & \text { Compressive strength }(\mathrm{MPa}) \\ f_{s p}^{\prime} & \text { Splitting strength }(\mathrm{MPa})\end{array}$




\section{REFERENCES}

1. ASTM (E 488-2003), "Standard Test Methods for Strength of Anchors in Concrete and Masonry Elements" Annual Book of ASTM Standards, VOL.04.11, 2003.

2. ACI Committee, "Building Code Requirements for Structural Concrete (ACI 318-02) and commentary (R318-02), American concrete institute, Farmington Hills, Michigan, 2002, pp.

3. Eligehausen, R., Breen, J., B., and Fuchs, W., (1995), ”Concrete capacity Design (CCD) Approach for Fastening to Concrete", ACI structural journal, V.92, No.1, January-February 1995, pp. 73-94.

4. Klingner, R. E. and Mendoca, J.A. (1982), "Tensile Capacity of Short Anchor Bolts Welded Studs: A Literature Review”, ACI Journal, Vol.79, No.27, July-August 1982, pp.270-279.

5. ACI Subcommittee 544.01, (1989), "State-of-the Art Report on Fiber Reinforced Concrete", Ch.2, Oct.1989, pp. 1-42.

6. A. A. M. Al-Sab'awy, 'Tensile Capacity of Short Anchor Bolts Embedded in Steel Fiber Reinforced Concrete", M.Sc. Thesis, Mosul University, Feb. 2006, 121 pp.

7. Souroshian, P., and Lee, C.D., "Constitutive Modeling of Steel Fibre Reinforced Concrete under Direct Tension and Compression", International Conference on Recent Developments in Fibre Reinforced Cement and Concrete, Cardiff, U.K., Sept. 1989, pp. 363-377.

8. Gesöglu, M., Tözturan, M. özel, and Güneyisi, E. (2005) "Tensile Behavior of Post- Installed Anchors in Plain and Steel Fiber-Reinforced Normal-and High-Strength Concretes" ACI Structural Journal, Vol. 102, No. 2, March-April 2005, pp.224-231.

9. Morgan, A. S. E., Niwa, J., and Tanabe, T. (1999) "Size effect Analysis for Pullout Strength Under Various Boundary Conditions”, Journal of Structural Engineering, Vol.122, No.9, Sep. 1996, pp. 1016-1024.

10. RILEM. (1991), "Fracture Mechanics of Concrete - Applications, Round Robin Analysis of Anchor Bolts", Preliminary Rep. TC 90-FMA, $2^{\text {nd }}$ ed. Reunion International des Laboratoires d'Essais et de Recherché sur les Materiaux et les Construction.

11. ACI Committee 544, "Design Consideration for Steel Fiber Reinforced Concrete", ACI Structural Journal, Vol.85,N0.5, sept.-Oct. 1988, pp. 563-580.

12. Swamy, R., N., and Stavrides, H. (1975), " Some Properties of High Workability Steel Fiber Concrete ", RILEM Symposium on Fibre Reinforced Cement and Concrete, The Construction Press Ltd., London, Sept. 1975, pp. 197-208.

13. Klinger, R. E., Shirvani, M. and Graves, H., L. (2004), "Breakout Capacity of Anchors in Concrete, Part 1: Tension”, ACI Structural Journal, Vol. 101, No. 6, May-June 2004, pp. 812-821.

14. Farrow, C. Ben, Frigui, I. and Klingner, R. E. (1996), "Tensile Capacity of Single Anchors in Concrete: Evaluation of Existing Formulas on an LRFD Basis", ACI Structural Journal, Vol. 93, No. 3, Jan. - Feb. 1996, pp.128-137.

The work was carried out at the University of Mosul 